\title{
PENERAPAN MODEL LIGHTHILL WHITHAM RICHARD (LWR) PADA JALAN TANJUNGPURA PONTIANAK MENGGUNAKAN PENDEKATAN MERGING DAN DIVERGING
}

\author{
Yuni Sarah, Helmi, Woro Budiartini Partiwi
}

\section{INTISARI}

\begin{abstract}
Masalah arus lalu lintas di jalan raya dapat dipengaruhi oleh kecepatan, kepadatan, arus lalu lintas, posisi kendaraan dan waktu yang dinyatakan sebagai variabel-variabel yang ada di jalan raya. Arus lalu lintas dapat dimodelkan berdasarkan variabel-variabel yang ada di jalan raya disebut sebagai variabel dasar makroskopik pada lalu lintas. Salah satu model yang dapat digunakan pada model makroskopik adalah model Lighthill Whitham Richard. Variabel makroskopik yang digunakan pada model LWR yaitu kecepatan (v), kepadatan ( $\rho)$, dan arus (q). Selanjutnya menggunakan metode masalah Riemann sehingga didapat model arus total merging dan diverging. Penelitian ini diterapkan pada jalan Tanjungpura untuk menghitung arus total merging dan diverging pada pukul 06.30-07.30 WIB, 13.00-14.00 WIB, dan 16.0017.00 WIB. Berdasarkan hasil simulasi diperoleh kepadatan lalu lintas pada jalan Tanjungpura meningkat pada pukul 06.45 WIB dan 16.12 WIB.
\end{abstract}

Kata Kunci: Arus Lalu Lintas, Masalah Riemann, Tingkat Kepadatan

\section{PENDAHULUAN}

Lalu lintas adalah pergerakan kendaraan dan pejalan kaki dari suatu tempat ke tempat lainnya, sehingga memudahkan manusia untuk sampai ke suatu lokasi tertentu [1]. Interaksi antara satu kendaraan dengan kendaraan lainnya disebut sebagai arus lalu lintas. Interaksi yang terjadi dapat mempengaruhi pergerakan arus pada suatu jalan raya yaitu arus lalu lintas berjalan lancar atau tidak berjalan lancar. Masalah arus lalu lintas di jalan raya dapat dipengaruhi oleh kecepatan, kepadatan, arus lalu lintas, posisi kendaraan dan waktu yang dinyatakan sebagai variabel-variabel yang ada di jalan raya. Arus lalu lintas dapat dimodelkan berdasarkan variabel kecepatan, kepadatan, dan arus lalu lintas yang disebut sebagai variabel dasar makroskopik pada lalu lintas [2]. Model matematika yang digunakan pada penelitian ini adalah model Lighthill-Whitham-Richard (LWR), model ini merupakan model yang menggambarkan fenomena lalu lintas yang dihasilkan dari interaksi banyak kendaraan dengan variabel dasar makroskopik dan diterapkan pada persimpangan merging dan diverging.

Tujuan penelitian ini adalah (1) membentuk model Lighthill Whitham Richard (LWR) pada arus lalu lintas, (2) membentuk model merging dan diverging menggunakan model Lighthill Whitham Richard (LWR), dan (3) penerapan model Lighthill Whitham Richard (LWR) pada jalan Tanjungpura Pontianak menggunakan pendekatan merging dan diverging. Penelitian ini membahas tentang model LWR yang diterapkan pada persimpangan merging dan diverging pada jalan Tanjungpura Pontianak dengan lama waktu lampu lalu lintas (siklus) yaitu 62 detik dan perilaku pengendara diabaikan. Panjang jalan yang diamati yaitu jalan Tanjungpura sebesar $100 \mathrm{~m}$ dengan lebar jalan 7,5 $\mathrm{m}$, jalan Diponegoro sebesar $100 \mathrm{~m}$ dengan lebar jalan $5 \mathrm{~m}$, dan jalan H. Agus Salim sebesar $100 \mathrm{~m}$ dengan lebar jalan sebesar $5 \mathrm{~m}$.

Hubungan antara variabel makroskopik disebut sebagai arus lalu lintas fundamental yaitu $q=\rho v$, dengan $q$ adalah arus, $\rho$ adalah kepadatan, dan $v$ adalah kecepatan. Berdasarakan arus lalu lintas fundamental dengan menerapkan persamaan diferensial parsial maka diperoleh model LWR. Kemudian digunakan metode masalah Riemann untuk menghasilkan model baru LWR pada persimpangan. Berdasarakan metode masalah Riemann diperoleh model persimpangan merging dan $d$ 
diverging yang diterapkan ke jalan Tanjungpura Pontianak.

\section{MODEL LIGHTHILL WHITHAM RICHARD (LWR)}

Secara umum, nilai kepadatan yang ada di sebuah jalur adalah sekitar satu kendaraan per 6,5 meter per jalur dan nilai kepadatan ketika arus maksimum adalah satu kendaraan per 32 meter [3]. Misalkan pergerakan kendaraan dengan kecapatan konstan $v_{0}$, dan dengan kepadatan konstan $\rho_{0}$, seperti yang ditunjukkan oleh Gambar 1

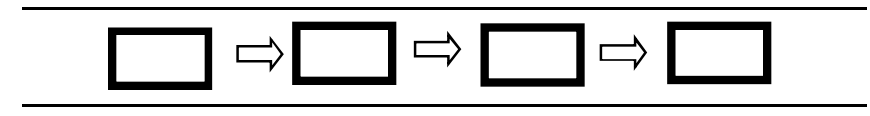

Gambar 1. Arus Lalu Lintas Kendaraan Konstan

Setiap kendaraan melaju dengan kecepatan yang sama, mengakibatkan jarak antara masing-masing kendaraan akan konstan, sehingga kepadatan lalu lintas (traffic densitas) tidak berubah.

Jika variabel lalu lintas tergantung pada $x$ dan $t$, maka dapat dituliskan menjadi

$$
q(x, t)=\rho(x, t) v(x, t) .
$$

Misalkan terdapat sejumlah kendaraan yang lewat pada Persamaan (1) yaitu $x=x_{0}$ di selisih waktu yang sangat kecil $\Delta t$, sedemikan sehingga $t_{0}$ dan $t_{0}+\Delta t$ kendaraan tidak dapat bergerak jauh sehingga jika $\rho$ dan $v$ merupakan fungsi yang kontinu terhadap $x$ dan $t$, maka $v(x, t)$ dan $\rho(x, t)$ dapat diaproksimasi dengan konstanta yang nilainya $x=x_{0}$ dan $t=t_{0}$. Kendaraan yang melaju dengan jarak yang pendek diaproksimasi dengan menggunakan $v(x, t) \Delta t$, sedangkan jumlah kendaraan yang lewat dapat dihitung sebagaimana rumusan awal yaitu $v(x, t) \Delta t \rho(x, t)$.

Diketahui bahwa variabel yang utama dalam arus lalu lintas adalah kepadatan lalu lintas $(\rho(x, t))$ dan kecepatan $(v(x, t))$. Gerak setiap kendaraan akan memenuhi persamaan diferensial orde pertama yaitu

$$
\frac{d x}{d t}=v(x, t), x(0)=x_{0},
$$

misalkan di jalan raya memiliki interval yaitu pada saat posisi $x=a$ dan $x=b$, maka dapat dirumuskan jumlah kendaraan yaitu [4].

$$
N=\int_{a}^{b} \rho(x, t) d x .
$$

Arus kendaraan setiap jalan $a$ dan $b$ diberikan dengan $q(a, t)$ dan $q(b, t)$. Sehingga laju perubahan jumlah kendaraan $\left(\frac{d N}{d t}\right)$ per waktu yang masuk melalui $x=a$ dikurangi dengan jumlah kendaraan per waktu yang keluar melalui $x=b$ atau dapat dirumuskan sebagai berikut

$$
\frac{d N}{d t}=q(a, t)-q(b, t)
$$

karena jumlah kendaraan per unit waktu dikatakan sebagai arus (flow) yang diberikan dengan $q(x, t)$ substitusikan Persamaan (2) ke Persamaan (3) sehingga

$$
\frac{\partial}{\partial t} \int_{a}^{b} \rho(x, t) d x=q(a, t)-q(b, t) .
$$

Jika $a=a$ dan $b=a+\Delta a$ maka Persamaan (4) dapat dimodifikasi menjadi sebagai berikut

$$
\frac{\partial}{\partial t} \int_{a}^{a+\Delta a} \rho(x, t) d x=q(a, t)-q(a+\Delta a, t),
$$

selanjutnya mengalikan kedua ruas Persamaan (5) dengan $\lim _{\Delta a \rightarrow 0} \frac{1}{-\Delta a}$ diperoleh 


$$
\lim _{\Delta a \rightarrow 0} \frac{1}{-\Delta a} \frac{\partial}{\partial t} \int_{a}^{a+\Delta a} \rho(x, t) d x=\lim _{\Delta a \rightarrow 0} \frac{q(a, t)-q(a+\Delta a, t)}{-\Delta a},
$$

pada ruas kanan Persamaan (6) merupakan definisi turunan parsial dengan $t$ tetap, atau yang lebih sering dikatakan sebagai

$$
\lim _{\Delta a \rightarrow 0} \frac{q(a, t)-q(a+\Delta a, t)}{-\Delta a}=\left(\frac{\partial}{\partial a}\right) q(a, t),
$$

sedangkan ruas kiri merupakan limitnya, integral menyatakan luas daerah di bawah kurva $\rho(x, t)$ antara $x=a$ dan $x=a+\Delta a$, dengan $\Delta a$ sangat kecil maka jumlah kendaraan antara $x=a$ dan $x=a+\Delta a$ adalah

$$
\lim _{\Delta a \rightarrow 0} \frac{1}{-\Delta a} \int_{a}^{a+\Delta a} \rho(x, t) d x \approx-\rho(a, t) .
$$

Berdasarkan Persamaan (7) dan Persamaan (8) maka Persamaan (6) diperoleh

$$
\begin{aligned}
\frac{\partial}{\partial a}(q(a, t)) & =-\frac{\partial}{\partial t} \rho(a, t) \\
\frac{\partial}{\partial a}(q(a, t))+\frac{\partial}{\partial t} \rho(a, t) & =0,
\end{aligned}
$$

karena variabel $a$ merupakan posisi maka $a=x$ sehingga Persamaan (9) menjadi

$$
\frac{\partial}{\partial x}(q(x, t))+\frac{\partial}{\partial t} \rho(x, t)=0 .
$$

Diketahui bahwa $q=\rho v$ maka disubstitusikan ke Persamaan (10) diperoleh

$$
\frac{\partial}{\partial x}(\rho v(x, t))+\frac{\partial}{\partial t} \rho(x, t)=0 .
$$

Persamaan (11) merupakan model LWR, model ini dapat digunakan untuk memprediksikan tingkat kepadatan yang akan datang dengan mengetahui tingkat kepadatan mula-mula.

\section{MASALAH RIEMANN}

Pengemudi yang bereaksi terhadap kecepatan kendaraan pada kepadatan sekitar dalam model LWR dapat ditulis sebagai

$$
v(x, t)=v(\rho(x, t) .
$$

Diasumsikan bahwa hubungan antara kecepatan dan kepadatan adalah suatu fungsi turun $\left(\frac{\partial v}{\partial \rho}<0\right)$ yang didefinisikan pada interval $\left[0, \rho_{\max }\right]$ dengan [5]:

a. $v(0)=v_{\max }$ yaitu, kecepatan maksimal ketika jalan sepi atau kosong.

b. $v\left(\rho_{\max }\right)=0$ yaitu, kecepatan berkurang sehingga berhenti ketika kepadatan maksimal dan mengakibatkan kemacetan.

Suatu persimpangan terdapat beberapa jalan masuk dan jalan keluar, sehingga digunakan metode masalah Riemann untuk mencari model LWR pada persimpangan. Masalah Riemann merupakan metode supply-demand yang berarti persediaan dan permintaan [6]. Misalkan ruang $\Delta x$ dan waktu $\Delta t$ konstan, dan $\rho_{i}^{t}$ adalah rata-rata dari $\rho$ pada jalur $i$ pada waktu $t$. Sedangkan arus masuk dari jalur $i$ pada waktu $t$ ke $t+1$ yaitu $q_{i-\frac{1}{2}}^{t+\frac{1}{2}}$ dan arus keluar dari jalur $i$ pada waktu $t$ ke $t+1$ yaitu $q_{i+\frac{1}{2}}^{t+\frac{1}{2}}$, maka model baru LWR untuk persimpangan pada jalur $i$ bisa dengan pendekatan menggunakan persamaan diferensiasi terbatas yaitu 


$$
\frac{q_{i-\frac{1}{2}}^{t+\frac{1}{2}}-q_{i+\frac{1}{2}}^{t+\frac{1}{2}}}{\Delta x}+\frac{\rho_{i}^{t+1}-\rho_{i}^{t}}{\Delta t}=0 .
$$

Misalkan sel keluar $i-1$ dan sel masuk $i$, maka kepadatan keluar $\rho_{i-1}^{t}$ dan masuk $\rho_{i}^{t}$ pada waktu $t$. Permintaan lalu lintas dari $i-1$ disebut arus pengirim yang ditulis sebagai $D_{i-1}^{t+\frac{1}{2}}$, dan penawaran lalu lintas dari $i$ disebut arus penerima yang ditulis sebagai $S_{i}^{t+\frac{1}{2}}$. Misalkan penawaran adalah arus maksimum yang dapat dikeluarkan oleh sel $i-1$ dari waktu $t$ ke $t+1$. Penawaran $S_{i}^{t+\frac{1}{2}}$ adalah arus maksimum yang dapat diterima oleh sel $i$, dengan demikian batas arus memenuhi

$$
\begin{aligned}
& q_{i-\frac{1}{2}} \leq D_{i-1} \\
& q_{i-\frac{1}{2}} \leq S_{i} .
\end{aligned}
$$

Diasumsikan bahwa batas arus optimal selalu mencapai maksimumnya, oleh karena itu batas arus dapat dihitung dengan [7]

$$
q_{i-\frac{1}{2}}=\min \left(D_{i-1}, S_{i}\right)
$$

\section{PERSIMPANGAN MERGING}

Persimpangan merging merupakan suatu persimpangan dengan dua jalan masuk dan satu jalan keluar, yang dapat dilihat Gambar 2

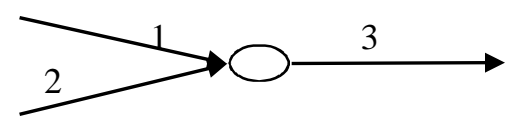

Gambar 2. Persimpangan Merging

Masalah arus pada persimpangan merging dapat dituliskan sebagai

$$
\max \overline{q_{3}},
$$

sehingga

$$
\begin{aligned}
\overline{q_{1}}+\overline{q_{2}} & =\overline{q_{3}} \\
\overline{q_{1}} & =\beta_{1} \overline{q_{3}} \\
\overline{q_{2}} & =\beta_{2} \overline{q_{3}} \\
\overline{q_{1}} & \in\left[0, q_{1}^{*}\right] \\
\overline{q_{2}} & \in\left[0, q_{2}^{*}\right] \\
\overline{q_{3}} & \in\left[0, q_{3}^{*}\right],
\end{aligned}
$$

mempunyai solusi tunggal [8].

Masalah Riemann merupakan metode supply-demand yang berarti persediaan dan permintaan dan masalah arus pada persimpangan merging memiliki solusi tunggal maka berdasarkan Persamaan (13) arus yang melalui batas jalur adalah jumlah minimum dari "pemasukan" bagi jalur penerima dan "pengeluaran" dari jalur pengirim, dengan waktu $t$ ke $t+1$. Asumsi dalam metode supply-demand untuk menghitung arus persimpangan merging agar mencapai batas optimal, maka terdapat dua kondisi optimalisasi yaitu arus total $\overline{q_{3}}=\overline{q_{1}}+\overline{q_{2}}$ mencapai maksimumnya dan arus $\overline{q_{1}}$ dan $\overline{q_{2}}$ mencapai maksimum masing-masing. Misalkan "pengirim" adalah $S_{1}$ dan $S_{2}$ sedangkan "penerima" adalah $D_{3}$, sehingga untuk mengoptimalisasi persimpangan merging yaitu

dengan

$$
\max \overline{q_{3}}=\overline{q_{1}}+\overline{q_{2}},
$$

$$
\begin{aligned}
& \overline{q_{1}} \leq S_{1} \\
& \overline{q_{2}} \leq S_{2}
\end{aligned}
$$


selanjutnya diperoleh arus total yaitu

$$
\begin{aligned}
\overline{q_{1}}+\overline{q_{2}} & \leq S_{1}+S_{2} \\
\overline{q_{1}}+\overline{q_{2}} & \leq D_{3} \\
\overline{q_{1}}, \overline{q_{2}} & \geq 0,
\end{aligned}
$$

$$
\begin{aligned}
& \overline{q_{3}}=\min \left(S_{1}+S_{2}, D_{3}\right) \\
& \overline{q_{3}}=\min \left(\sum_{i=1}^{2} S_{i}, D_{3}\right),
\end{aligned}
$$

karena perilaku pengendara diabaikan maka tidak ada pengendara yang melewati jalur lain. Jadi arus total merging yaitu

$$
\overline{q_{3}}=S_{1}+S_{2}=D_{3}
$$

\section{PERSIMPANGAN DIVERGING}

Persimpangan diverging merupakan suatu persimpangan dengan satu jalan masuk dan dua jalan keluar, yang dapat dilihat pada Gambar 3 berikut.

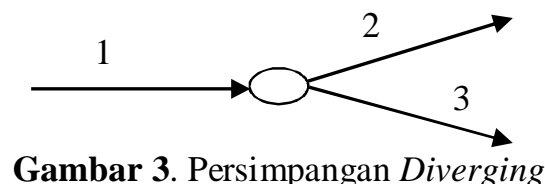

Masalah arus pada persimpangan diverging dapat dituliskan sebagai

sehingga

$$
\max \overline{q_{1}} \text {, }
$$

mempunyai solusi tunggal.

$$
\begin{aligned}
\overline{q_{1}} & =\overline{q_{2}}+\overline{q_{3}} \\
\alpha_{2} \overline{q_{1}} & =\overline{q_{2}} \\
\alpha_{3} \overline{q_{1}} & =\overline{q_{3}} \\
\overline{q_{1}} & \in\left[0, q_{1}^{*}\right] \\
\overline{q_{2}} & \in\left[0, q_{2}^{*}\right] \\
\overline{q_{3}} & \in\left[0, q_{3}^{*}\right],
\end{aligned}
$$

Masalah Riemann merupakan metode supply-demand yang berarti persediaan dan permintaan dan masalah arus pada persimpangan diverging memiliki solusi tunggal maka berdasarkan Persamaan (13) arus yang melalui batas jalur adalah jumlah minimum dari "pemasukan" bagi jalur penerima dan "pengeluaran" dari jalur pengirim, dengan waktu $t$ ke $t+1$. Asumsi untuk menghitung arus persimpangan diverging agar mencapai batas optimal, maka terdapat dua kondisi optimalisasi yaitu arus total $\overline{q_{1}}=\overline{q_{2}}+\overline{q_{3}}$ mencapai maksimumnya dan arus $\overline{q_{2}}$ dan $\overline{q_{3}}$ mencapai maksimum masingmasing. Misalkan "pengirim" adalah $S_{1}$ sedangkan "penerima" adalah $D_{2}$ dan $D_{3}$, sehingga untuk mengoptimalisasi persimpangan diverging yaitu

dengan

$$
\max \overline{q_{1}}=\overline{q_{2}}+\overline{q_{3}},
$$

$$
\begin{aligned}
& \overline{q_{2}} \leq D_{2} \\
& \overline{q_{3}} \leq D_{3}
\end{aligned}
$$


sehingga diperoleh arus total yaitu

$$
\begin{gathered}
\overline{q_{2}}+\overline{q_{3}} \leq D_{2}+D_{3} \\
\overline{q_{2}}+\overline{q_{3}} \leq S_{1} \\
\overline{q_{2}}, \overline{q_{3}} \geq 0,
\end{gathered}
$$

$$
\begin{aligned}
& \overline{q_{1}}=\min \left(D_{2}+D_{3}, S_{1}\right) \\
& \overline{q_{1}}=\min \left(\sum_{i=2}^{3} D_{i}, S_{1}\right),
\end{aligned}
$$

karena perilaku pengendara diabaikan maka tidak ada pengendara yang melewati jalur lain. Jadi arus total merging yaitu

$$
\overline{q_{1}}=D_{2}+D_{3}=S_{1}
$$

\section{KAPASITAS DAN TINGKAT ARUS JALAN}

Kapasitas jalan di bagi menjadi tiga kategori yaitu lengang, sedang, dan padat dengan konsentrasi maksimum masing-masing $\frac{1}{3}, \frac{2}{3}, \frac{3}{3}$ dari total kapasitas kendaraan yang dapat ditampung dalam radius tertentu. Simbol pewarnaannya adalah hijau untuk lengang, kuning untuk sedang, dan merah untuk padat. Kapasitas jalan dapat dihitung dengan [9].

$$
\text { Kapasitas jalan }=\frac{\text { Luas Jalan }}{\text { Luas Kendaraan }}
$$

Sebelum menentukan kapasitas jalan diasumsikan bahwa :

a. Semua kendaraan adalah sejenis, yaitu panjang kendaraan $2 \mathrm{~m}$ dan lebar kendaraan $1,5 \mathrm{~m}$, sehingga luasnya sebesar $3 \mathrm{~m}^{2}$.

b. Jalan Tanjungpura terbagi menjadi dua yaitu jalan Tanjungpura 1 dan Tanjugpura 2. Jalan Tanjungpura 1 yaitu jalan dari arah utara ditandai dengan garis merah sedangkan jalan Tanjungpura 2 dari arah selatan ditandai dengan garis berwarna biru. Pembagian jalan Tanjungpura dapat dilihat pada Gambar 4.

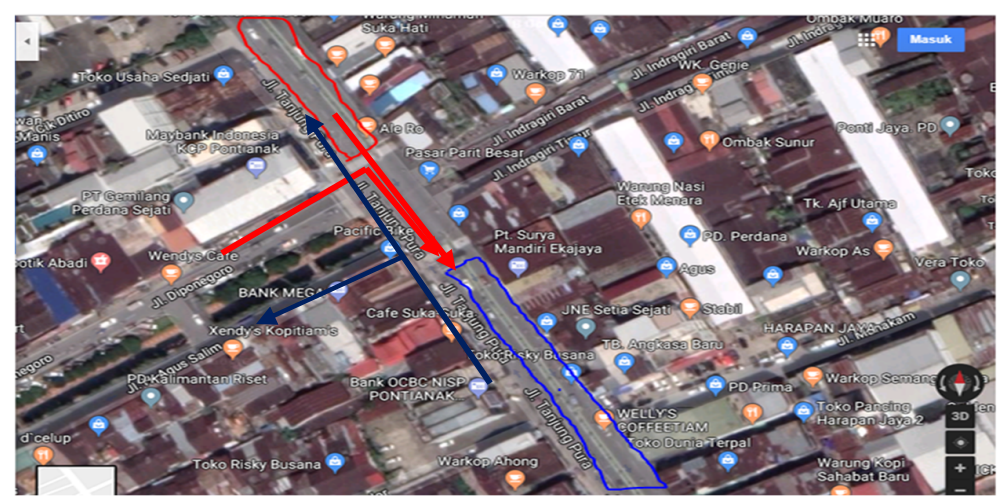

Gambar 4. Persimpangan Jalan Tanjungpura

(Sumber: Google Maps)

Berdasarkan Persamaan (14) maka diperoleh kapasitas jalan Tanjungpura, Diponegoro dan H. Agus Salim yaitu dapat dilihat pada Tabel 1 .

Tabel 1. Kapasitas Jalan

\begin{tabular}{|c|c|c|l|c|}
\hline \multirow{2}{*}{ Jalan } & \multicolumn{4}{|c|}{ Tingkat Kepadatan } \\
\cline { 2 - 5 } & Lengang & Sedang & Padat & Total \\
\hline \multirow{2}{*}{ Tanjungpura } & $0-84$ & $85-167$ & $168-$ & 250 \\
& & & 250 & \\
\hline
\end{tabular}




\begin{tabular}{|c|c|c|c|c|}
\hline Diponegoro & $0-56$ & $57-112$ & $\begin{array}{c}113 \\
-167\end{array}$ & 167 \\
\hline $\begin{array}{c}\text { H.Agus } \\
\text { Salim }\end{array}$ & $0-56$ & $57-112$ & $\begin{array}{c}113 \\
-167\end{array}$ & 167 \\
\hline
\end{tabular}

Kemudian dilakukan perhitungan jumlah kendaraan dari arah Tanjungpura 1 dan dari arah Diponegoro ke arah Tanjungpura 2, dan dari arah Tanjungpura 2 ke arah H. Agus Salim dan ke arah Tanjungpura 1 di setiap lampu lalu lintas pada pukul 06.30-07.30 WIB, pukul 13.00-14.00 WIB dan pukul 16.0017.00 WIB. Jumlah kendaraan dari masing-masing jalan merupakan total dari seluruh kendaraan yang berjenis motor, mobil, dan truk/bus/kontainer yang dapat dilihat pada Gambar 5 berikut.

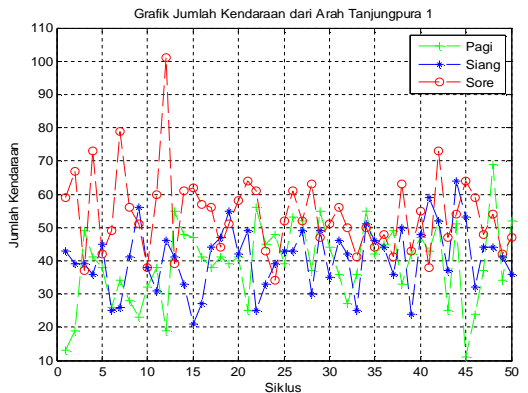

(a) Grafik Jumlah Kendaraan dari Arah Tanjungpura 1

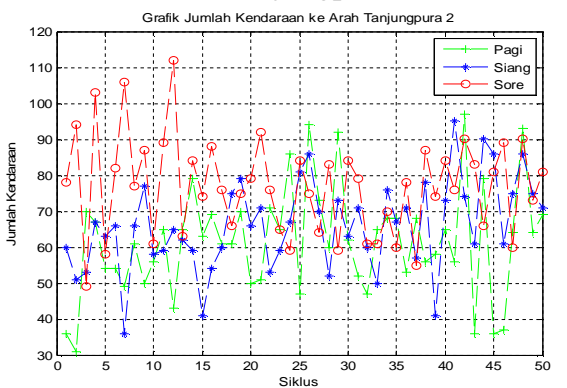

(c) Grafik Jumlah Kendaraan ke Arah Tanjungpura 2

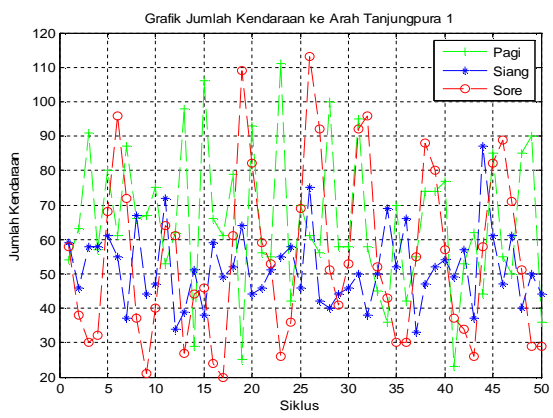

(e) Grafik Jumlah Kendaraan ke Arah Tanjungpura 1

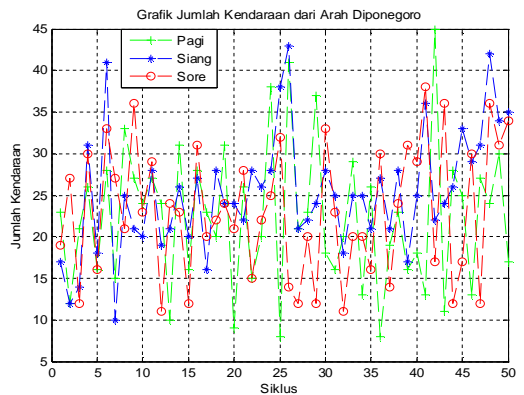

(b) Grafik Jumlah Kendaraan dari Arah Diponegoro

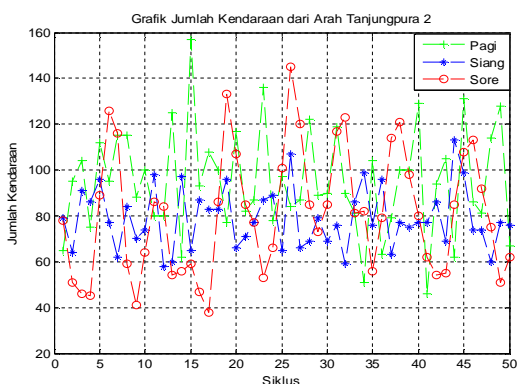

(d) Grafik Jumlah Kendaraan dari Arah Tanjungpura 2

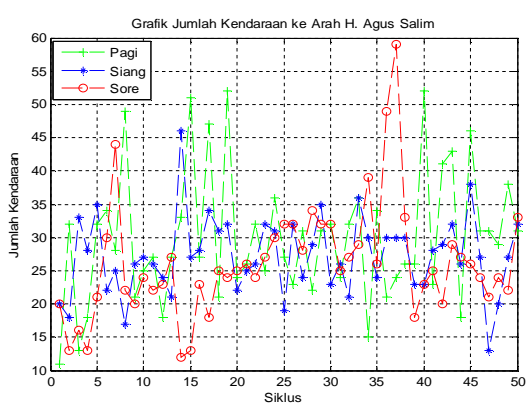

(f) Grafik Jumlah Kendaraan ke Arah H. Agus Salim

Gambar 5. Grafik Jumlah Kendaraan Masing-Masing Jalan pada Pagi, Siang, dan Sore Hari (a) Grafik Jumlah Kendraan dari Arah Tanjungpura 1 (b) Grafik Jumlah Kendraan dari Arah Diponegoro. (c) Grafik Jumlah Kendraan ke Arah Tanjungpura 2 (d) Grafik Jumlah Kendraan dari Arah Tanjungpura 2 (e) Grafik Jumlah Kendraan ke Arah Tanjungpura 1 (f) Grafik Jumlah Kendraan ke Arah H. Agus Salim.

Berdasarkan Gambar (a) dapat dilihat bahwa jumlah kendaraan dari arah Tanjungpura 1 meningkat paling banyak pada saat sore hari yaitu pukul 16.12 WIB sebanyak 101 kendaraan. Berdasarkan 
Gambar 5 (b) dapat dilihat jumlah kendaraan dari arah Diponegoro meningkat paling banyak pada saat pagi hari yaitu pukul 07.13 WIB sebanyak 45 kendaraaan. Berdasarkan Gambar 5 (c) dapat dilihat bahwa jumlah kendaraan ke arah Tanjungpura 2 meningkat paling banyak pada saat sore hari yaitu pukul 16.12 WIB sebanyak 112 kendaraan. Berdasarkan Gambar 5 (d) dapat dilihat bahwa jumlah 
kendaraan dari arah Tanjungpura 2 meningkat paling banyak pada saat pagi hari yaitu pukul 07.15 WIB sebanyak 157 kendaraan. Berdasarkan Gambar 5 (e) dapat dilihat bahwa jumlah kendaraan ke arah Tanjungpura 1 meningkat paling banyak pada saat sore hari yaitu pukul 16.26 WIB sebanyak 113 kendaraan. Berdasarkan Gambar 5 (f) dapat dilihat bahwa jumlah kendaraan ke arah H. Agus Salim meningkat paling banyak pada saat sore hari yaitu pukul 16.38 WIB sebanyak 59 kendaraan.

Sedangkan arus kendaraan diperoleh dari jumlah kendaraan per waktu lampu lalu lintas. Oleh karena itu berdasarkan jumlah kendaraan yang ditunjukkan oleh Gambar 5 maka diperoleh arus dari masingmasing jalan yang dapat dilihat pada Gambar 6 .

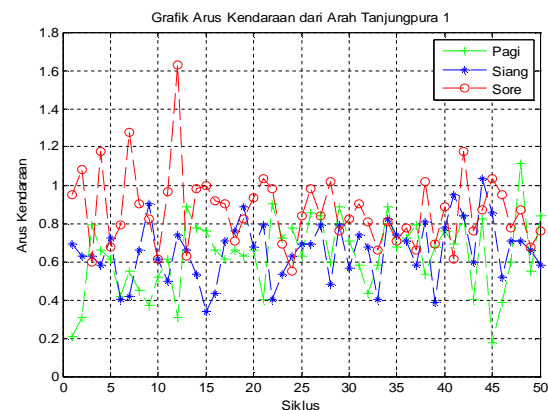

(a) Grafik Arus Kendaraan dari Arah Tanjungpura 1

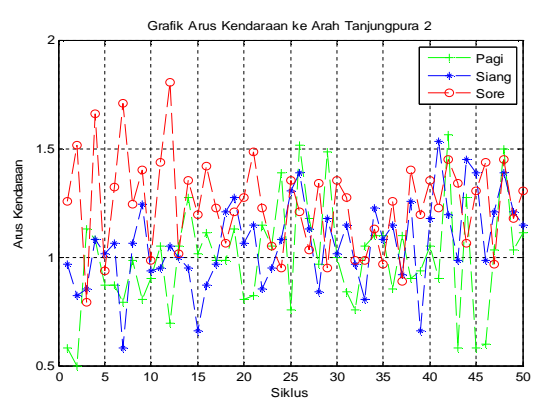

(c) Grafik Arus Kendaraan ke Arah Tanjungpura 2

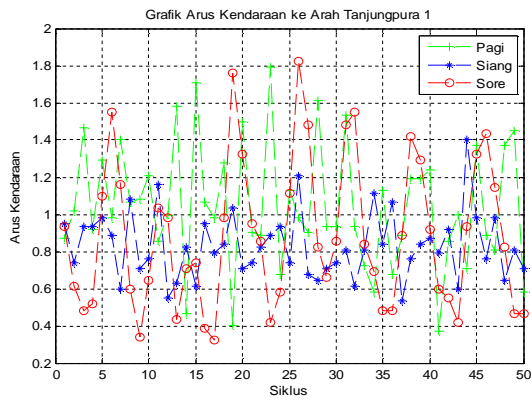

(e) Grafik Arus Kendaraan ke Arah Tanjungpura 1

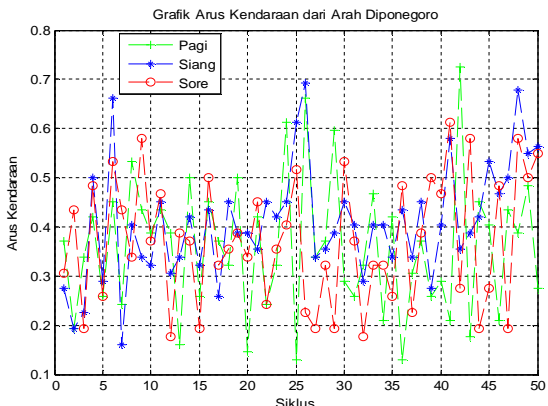

(b) Grafik Arus Kendaraan dari Arah Diponegoro

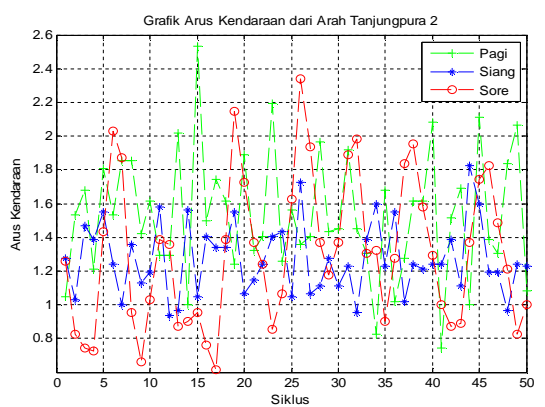

(d) Grafik Arus Kendaraan dari Arah Tanjungpura 2

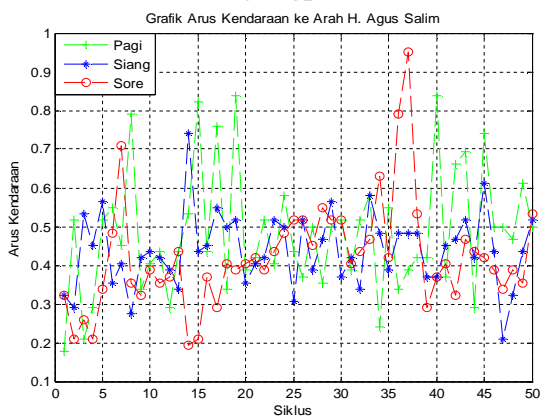

(f) Grafik Arus Kendaraan ke Arah H. Agus Salim

Gambar 6. Grafik Arus Kendaraan Masing-Masing Jal an pada Pagi, Siang, dan Sore Hari (a) Grafik Arus Kendraan dari Arah Tanjungpura 1 (b) Grafik Arus Kendraan dari Arah Diponegoro (c) Grafik Arus Kendraan ke Arah Tanjungpura 2 (d) Grafik Arus Kendraan dari Arah Tanjungpura 2 (e) Grafik Arus Kendraan ke Arah Tanjungpura 1 (f) Grafik Arus Kendraan ke Arah H. Agus Salim.

Berdasarkan Gambar 6 (a) dapat dilihat bahwa arus kendaraan dari arah Tanjungpura 1 meningkat paling banyak pada saat sore hari yaitu pukul 16.12 WIB sebesar 1,63. Berdasarkan Gambar 6 (b) dapat dilihat bahwa arus kendaraan dari arah Diponegoro meningkat paling banyak pada saat pagi hari yaitu pukul 07.13 WIB sebesar 0,73. Berdasarkan Gambar 6 (c) dapat dilihat bahwa arus kendaraan 
dari arah Diponegoro meningkat paling banyak pada saat sore hari yaitu pukul 16.12 WIB sebesar 1,81. Berdasarkan Gambar 6 (d) dapat dilihat bahwa arus kendaraan dari arah Diponegoro meningkat paling banyak pada saat pagi hari yaitu pukul 06.45 WIB sebesar 2,53. Berdasarkan Gambar 6 (e) dapat dilihat bahwa arus kendaraan dari arah Diponegoro meningkat paling banyak pada saat sore hari yaitu pukul 16.26 WIB sebesar 1,82. Berdasarkan Gambar 6 (f) dapat dilihat bahwa arus kendaraan dari arah Diponegoro meningkat paling banyak pada saat sore hari yaitu pukul 16.38 WIB sebesar 0,95. Sehingga arus total merging dan diverging dapat dilihat pada Gambar 7.

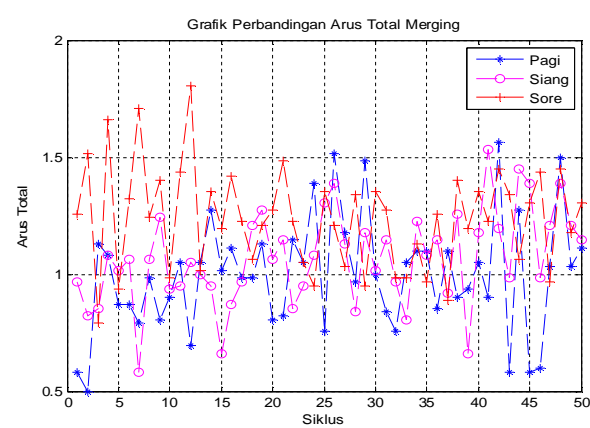

(a) Grafik Arus Total Merging

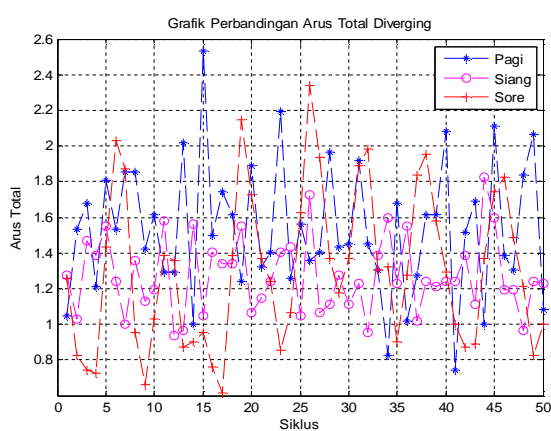

(b) Grafik Arus Total Diverging

Gambar 7. Grafik Arus Total Merging dan Diverging (a) Grafik Arus Total Merging (b) Grafik Arus Total Diveging.

Berdasarkan Gambar 7 dapat dilihat bahwa arus total merging meningkat pada siklus ke-12 yaitu pukul 16.12 WIB sebesar 1,81 dan diverging meningkat pada siklus ke-15 yaitu pukul 06.45 WIB sebesar 2,53.

\section{PENUTUP}

Kesimpulan yang dapat diambil dalam penelitian ini yaitu:

1. Berdasarkan hubungan antara variabel makroskopik diperoleh model arus lalu lintas LWR yaitu

$$
\frac{\partial}{\partial x}(q(x, t))+\frac{\partial}{\partial t}(\rho(x, t))=0
$$

dimana $q=\rho v$.

2. Berdasarkan model Lighthill-Whitham-Richard (LWR) didapat Model merging dan diverging sebagai berikut:

a. Merging

$$
\begin{aligned}
\max \overline{q_{3}} & =\overline{q_{1}}+\overline{q_{2}} \\
\overline{q_{3}} & =\min \left(S_{1}+S_{2}, D_{3}\right) \\
\overline{q_{3}} & =\min \left(\sum_{i=1}^{2} S_{i}, D_{3}\right),
\end{aligned}
$$

karena perilaku pengendara diabaikan maka tidak ada pengendara yang melewati jalur lain. Jadi arus total merging yaitu

b. Diverging

$$
\overline{q_{3}}=S_{1}+S_{2}=D_{3}
$$

$$
\begin{aligned}
\max \overline{q_{1}} & =\overline{q_{2}}+\overline{q_{3}} \\
\overline{q_{1}} & =\min \left(D_{2}+D_{3}, S_{1}\right) \\
\overline{q_{1}} & =\min \left(\sum_{i=2}^{3} D_{i}, S_{1}\right),
\end{aligned}
$$

karena perilaku pengendara diabaikan maka tidak ada pengendara yang melewati jalur lain. Jadi arus total merging yaitu 


$$
\overline{q_{1}}=D_{2}+D_{3}=S_{1}
$$

3. Model LWR yang dilakukan pada jalan Tanjungpura Pontianak menggunakan pendekatan merging dan diverging diperoleh, yaitu arus total diverging meningkat pada siklus ke-15 yaitu pukul 06.45 WIB sebesar 2,53 sedangkan arus total merging meningkat pada siklus ke-12 yaitu pukul 16.12 WIB sebesar 1,81.

\section{DAFTAR PUSTAKA}

[1] Pemerintah Indonesia. Undang-Undang No.22 Tahun 2009 tentang Lalu Lintas dan Angkutan Jalan. Lembaran Negara RI Tahun 2009 No.22, Sekretariat Negara, Jakarta; 2009.

[2] Yusnita Y. Simulasi Arus Lalu Lintas dengan Menggunakan Kecepatan Model Kerner Konhauser. Unrika. 2016; 5(2).

[3] Ploson N, Sokolov V. Bayesian Analysis of Traffic Flow on Interstate I-55: The LWR Model. The Annals of Applied Statistics. 2015; 4(9): 1864-188.

[4] Iswanto RJ. Pemodelan Matematika: Aplikasi dan Terapannya. Yogyakarta: Graha Ilmu; 2012.

[5] Haut B, Bastin G, Chitour Y. A Macroscopic Traffic Model for Road Network with a Representation of the Capacity Drop Phenomenon at the Junctions. IFAC Transportation System. 2005; (38): 114-119.

[6] Haut B, Bastin G. A Second Order of Road Junctions in Fluid Models of Traffic Networks. Networks and Heterogeneous Media. 2007; 2(2): 227-883.

[7] Jin W L, Zhang HM. On the Distibution Schemes for Determining Flows through a Merge. Transportation Reserch Part B. 2002; (37): 521-540.

[8] Haut B, Bastin G. A Second Order of Road Junctions in Fluid Models of Traffic Networks. Networks and Heterogeneous Media. 2007; 2(2): 227-883.

[9] Direktorat Jenderal Bina Marga Direktorat Bina Jalan Kota Republik Indonesia. Manual Kapasitas Jalan Indonesia (MKJI). Jakarta: Direktorat Jenderal Bina Marga; 1997.

YUNI SARAH

HELMI

WORO BUDIARTINI PARTIWI
: Jurusan Matematika FMIPA Untan, Pontianak, yunisarah479@gmail.com

: Jurusan Matematika FMIPA Untan, Pontianak, helmi132205@yahoo.co.id

: Jurusan Matematika FMIPA Untan, Pontianak, woro.partiwi@gmail.com 